\title{
ERYTHROCYTE PRESERVATION. V. RELATIONSHIP BETWEEN CHEMICAL CHANGES AND VIABILITY OF STORED BLOOD TREATED WITH ADENOSINE ${ }^{1}$
}

\author{
By BEVERLY WESCOTT GABRIO, D. M. DONOHUE, ANd C. A. FINCH
}

(From the Department of Medicine, University of Washington School of Medicine, and The King County Central Blood Bank, Seattle, Wash.)

(Submitted for publication March 21, 1955 ; accepted June 1, 1955)

Blood refrigerated in acid-citrate-dextrose is known to undergo marked derangement in carbohydrate metabolism and loss of viability during storage. Previous studies of the "storage lesion" have indicated that this metabolic deterioration is arrested once the red cell is introduced into the active circulation of the recipient, and that the ability of the red cells to withstand further in vitro storage is regained (1).

The addition of adenosine to stored blood has been shown to produce a repletion of cellular organic phosphates and an increased ability of the cells to oxidize glucose aerobically (2). Further data will be presented in this paper on the reversal of other storage changes and in particular the improved maintenance of the post-transfusion viability of the erythrocyte.

\section{MATERIALS AND METHODS}

Blood was stored routinely at $4^{\circ}$ in acid-citrate-dextrose (National Institutes of Health, Formula B). Measurements of the phosphate partition of red cells, concentration of adenosine, and adenosine uptake by red cells were performed as reported previously (2). Osmotic fragility of erythrocytes was measured by the technique of Shen, Ham, and Fleming (3). Potassium was determined on whole blood and plasma with the use of the Baird flame photometer. ${ }^{2}$

Post-transfusion survival of erythrocytes was estimated with the use of a double isotope technique (4). Stored cells were labelled with $\mathrm{Cr}^{\text {si }}$, and a measured amount of those cells of known radioactivity was injected. Simultaneously, the blood volume of the recipient was determined with fresh $\mathrm{P}^{\mathrm{w}}$-tagged cells. The total counts of

\footnotetext{
1 This investigation was supported in part by research grants from the United States Atomic Energy Commission (Contract AT (45-1)-343) and the Department of the Army, Office of the Surgeon General (Contracts DA-49-007-MD-508 and DA-49-007-MD-512) and State of Washington Initiative 171 funds for research in $\mathrm{Bi}$ ology and Medicine.

2 We are indebted to the laboratory of Dr. Belding $\mathbf{H}$. Scribner for these analyses.
}

$\mathrm{Cr}^{\mathrm{Cl}}$ injected divided by the blood volume gave the theoretical activity in counts per minute per milliliter in the recipient's blood. Post-transfusion samples at $1,2,3,5$, and 7 days were obtained for the determination of $\mathrm{Cr}^{\text {si }}$ activity. Since excessive destruction is limited to the first 48 hours and the slope thereafter approximates 1 per cent per day destruction, further samples were felt to be unnecessary. The ratio of radioactivity in the samples to the theoretical level of activity was plotted graphically and extrapolated to zero time. This value was designated per cent survival. With the use of this procedure, fresh rabbit and human blood have a survival in compatible recipients of 90 per cent. The initial loss is ascribed in part to washing of the cells, since unwashed fresh erythrocytes have 96 per cent survival.

$P^{2}$ activity was determined with the use of a heliumfilled Geiger tube. The counting efficiency of $P^{21}$ was 20 per cent, and the background was $23 \mathrm{cpm}$. $\mathrm{Cr}^{\mathrm{ol}}$ was measured in a well of a scintillation counter separated from the crystal by a 3/128 inch brass shield. Counting efficiency of $\mathrm{Cr}^{\text {st }}$ was 3 per cent with a background of 80 cpm. Cross counting of $\mathrm{Cr}^{\mathrm{si}}$ with the Geiger tube was less than 1 per cent, and $P^{* s}$ counts on the scintillation counter were less than 3 per cent of those obtained with the Geiger tube.

\section{RESULTS}

Studies to define more completely the effect of adenosine on the storage lesion have been conducted on both rabbit and human erythrocytes. The following experiments have been carried out repeatedly to assure the reproducibility of the phenomenon and its implications in terms of cell viability.

\section{Rabbit blood}

Rabbit blood, which had been collected in ACD and stored at $4^{\circ}$ for three weeks, was divided into two aliquots. Adenosine $(2,000 \mu \mathrm{M}$ per $100 \mathrm{ml}$. $\mathrm{RBC}$ ) was added to the first aliquot and saline to the other which served as a control. Both samples were then incubated for one hour at $37^{\circ}$ and stored thereafter at $4^{\circ}$ for three weeks additional, 
TABLE I

Chemistry and survival of stored rabbit blood after adenosine treatment

Rabbit blood was stored at $4^{\circ}$ in ACD for 20 days at which time it was divided into two aliquots: 1 ) Control with saline addition; 2) Adenosine $\left(2,000 \mu \mathrm{M}\right.$ per $100 \mathrm{ml}$. RBC) added. Both samples were incubated at $37^{\circ}$ for one hour and returned to $4^{\circ}$ refrigeration for subsequent storage.

\begin{tabular}{|c|c|c|c|c|c|c|}
\hline \multirow[b]{2}{*}{ Days' storage } & \multicolumn{3}{|c|}{$\mu \mathrm{M}$ P $/ 100 \mathrm{ml} . \mathrm{RBC}$} & \multirow{2}{*}{$\begin{array}{c}\text { Osmotic } \\
\text { fragility peak } \\
\text { (per cent NaCl)* }\end{array}$} & \multirow{2}{*}{\multicolumn{2}{|c|}{$\begin{array}{l}\text { Post-transfusion } \\
\text { gurvival } \\
\text { (per cent) }\end{array}$}} \\
\hline & Inorganic & Organic & $\begin{array}{l}\text { Increase in } \\
\text { organic }\end{array}$ & & & \\
\hline $\begin{array}{l}0 \text { day } \\
20 \text { day }\end{array}$ & $\begin{array}{r}173 \\
1,443\end{array}$ & $\begin{array}{l}2,408 \\
1,018\end{array}$ & & $\begin{array}{l}0.48 \\
0.54\end{array}$ & 77,77 & Av. \\
\hline $\begin{array}{l}20 \text { day; } 1 \mathrm{hr} \text {. rejuvenated: } \\
\text { Control } \\
\text { Adenosine }\end{array}$ & $\begin{array}{r}1,007 \\
698\end{array}$ & $\begin{array}{r}911 \\
1,665\end{array}$ & 754 & $\begin{array}{l}0.60 \\
0.52\end{array}$ & & \\
\hline $\begin{array}{l}\text { Control } \\
\text { Adenosine }\end{array}$ & $\begin{array}{r}1,625 \\
279\end{array}$ & $\begin{array}{r}601 \\
2,131\end{array}$ & 1,530 & $\begin{array}{l}0.60 \\
0.44\end{array}$ & $\begin{array}{l}65,66 \\
79,80\end{array}$ & $\begin{array}{l}66 \\
80\end{array}$ \\
\hline Control & $\begin{array}{r}1,688 \\
338\end{array}$ & $\begin{array}{r}542 \\
1,951\end{array}$ & 1,409 & $\begin{array}{l}0.60 \\
0.48\end{array}$ & $\begin{array}{l}53,53 \\
72,77\end{array}$ & $\begin{array}{l}53 \\
75\end{array}$ \\
\hline $\begin{array}{l}\text { Control } \\
\text { Adenosine }\end{array}$ & $\begin{array}{r}1,741 \\
694\end{array}$ & $\begin{array}{r}443 \\
1,657\end{array}$ & 1,214 & $\begin{array}{l}0.62 \\
0.48\end{array}$ & $\begin{array}{l}32,36 \\
60,70\end{array}$ & $\begin{array}{l}34 \\
65\end{array}$ \\
\hline
\end{tabular}

* Each value represents the concentration of $\mathrm{NaCl}$ at which there is the maximum tendency for the greatest number of cells to hemolyze. The fragility peak is obtained from a curve plotted with $\frac{\Delta \% \text { hemolysis }}{\Delta \% \mathrm{NaCl}}$ as abscissa and $\% \mathrm{NaCl}$ as ordinate (1).

thus representing a total storage time of 6 weeks. In Table $\mathrm{I}$, are recorded the data from one such experiment. During the first three weeks of storage, the organic phosphates of the red cell had decreased about $1400 \mu \mathrm{M}$ per $100 \mathrm{ml}$. RBC, the red cell fragility to hypotonic saline had increased, and the post-transfusion survival had declined to 77 per cent. After one hour of incubation, the cells treated with adenosine exhibited considerable resynthesis of organic phosphates and improvement in osmotic fragility. Although the initial uptake of 65 per cent of adenosine by the cells was essentially unchanged during the following week of storage at $4^{\circ}$, there was further synthesis of organic phosphates. Subsequent storage showed a gradual decline of organic phosphates in the adenosine-treated cells, but the content of phosphorylated compounds exceeded greatly that found in the untreated cells. The erythrocytes were less fragile in hypotonic saline after adenosine treatment.

Post-transfusion survival measurements were carried out in two recipient animals for each sample tested. As anticipated, the control blood at the 4th, 5th, and 6th week of storage decreased in viability from 66 to 53 to 34 per cent. During this same time the adenosine-treated blood showed a total decrease of only 12 per cent, that is, a fall from 77 to 65 per cent.

\section{Human blood}

A similar study was carried out on human blood, collected in ACD and stored at $4^{\circ}$. On the

TABLE II

Chemistry of stored human blood after adenosine treatment

Human blood was stored at $4^{\circ}$ in ACD for 21 days and then divided into two aliquots: 1) Control with saline addition; 2) Adenosine (2,500 $\mu \mathrm{M}$ per $100 \mathrm{ml}$. RBC) added. Both samples were incubated in a water bath at $37^{\circ}$ for one hour and returned to $4^{\circ}$ refrigeration for subsequent storage.

\begin{tabular}{|c|c|c|c|c|}
\hline \multirow[b]{2}{*}{ Days' storage } & \multicolumn{2}{|c|}{$\mu \mathrm{M} \mathrm{P} / 100 \mathrm{ml} . \mathrm{RBC}$} & \multirow{2}{*}{$\begin{array}{c}\text { Osmotic } \\
\text { fragility peak* } \\
\text { (per cent } \mathrm{NaCl} \text { ) }\end{array}$} & \multirow{2}{*}{$\underset{\substack{\mathrm{m} E_{q} / 1 \\
\mathrm{~K} C}}{\mathrm{~K}}$} \\
\hline & Inorganic & Organic & & \\
\hline $\begin{array}{l}0 \\
21 \\
21,1 \mathrm{hr} .\end{array}$ & $\begin{array}{l}125 \\
892\end{array}$ & $\begin{array}{r}1,430 \\
435\end{array}$ & $\begin{array}{l}.42 \\
.50\end{array}$ & \\
\hline $\begin{array}{l}\text { rejuvenated: } \\
\text { Control } \\
\text { Adenosine } \\
\text { 28, } 7 \text { days } \\
\text { reiuvenated: }\end{array}$ & $\begin{array}{r}556 \\
71\end{array}$ & $\begin{array}{r}480 \\
1,373\end{array}$ & $\begin{array}{l}.50 \\
.44\end{array}$ & $\begin{array}{l}56.9 \\
68.1\end{array}$ \\
\hline $\begin{array}{l}\text { Control } \\
\text { Adenosine } \\
\text { 42, } 21 \text { days }\end{array}$ & $\begin{array}{r}693 \\
64\end{array}$ & $\begin{array}{r}366 \\
1,031\end{array}$ & $\begin{array}{l}.52 \\
.44\end{array}$ & $\begin{array}{l}49.4 \\
55.2\end{array}$ \\
\hline $\begin{array}{l}\text { rejuvenated: } \\
\text { Control } \\
\text { Adenosine }\end{array}$ & $\begin{array}{l}817 \\
326\end{array}$ & $\begin{array}{r}273 \\
1,213\end{array}$ & $\begin{array}{l}.54 \\
.48\end{array}$ & $\begin{array}{l}38.3 \\
50.4\end{array}$ \\
\hline
\end{tabular}

* See legend, Table I. 
21st day of storage, the blood was divided into two aliquots and after saline solution was added to the control and adenosine $(2,500 \mu \mathrm{M}$ per $100 \mathrm{ml}$. $\mathrm{RBC}$ ) to the second, the aliquots were incubated for one hour and refrigerated. In general, the results of the chemical analyses (Table II) were similar to those observed with rabbit erythrocytes. The uptake of adenosine was 63 per cent after the one-hour incubation period and 68 per cent the following week. The cellular organic phosphates, particularly the easily hydrolyzable and non-hydrolyzable fractions, were increased after incubation with adenosine and were maintained well throughout the additional storage period. Osmotic fragility and intracellular potassium of the adenosine-treated erythrocytes reflected a similar improvement as compared with the control.

The viability of erythrocytes treated with adenosine showed essentially no change over the three weeks following incubation, while the control blood in acid-citrate-dextrose lost viability rapidly (Table III). Thus, at the total storage time of six weeks, the post-transfusion survival of ACD blood was 15 per cent, while the blood treated with adenosine was 87 per cent viable.

\section{DIŚCUSSION}

Stored in ACD at $4^{\circ}$ the red cell gradually undergoes a multiplicity of changes. Some or all of these changes may be presumed to have a direct bearing on the loss of viability of the cell in the sense of the cell's capacity to maintain itself in active circulation after transfusion and perform its oxygen-carrying functions. It has been established by previous workers in this field that while several of these in vitro tests may show a high degree of correlation with the viability of cells after transfusion, this is not invariably the case and that no

TABLE III

Survival of stored human blood after adenosine treatment *

\begin{tabular}{|c|c|c|}
\hline Days' storage & \multicolumn{2}{|c|}{$\begin{array}{l}\text { Post-trangfusion survival } \\
\text { (per cent) }\end{array}$} \\
\hline 7 daye reiuyenated. & & $\overline{\text { Av. }}$ \\
\hline $\begin{array}{l}\text { Control } \\
\text { Adenosine } \\
42,21 \text { days rejuvenated: }\end{array}$ & $\begin{array}{l}47,53,68 \\
67,69,82\end{array}$ & $\begin{array}{l}56 \\
73\end{array}$ \\
\hline $\begin{array}{l}\text { Control } \\
\text { Adenosine }\end{array}$ & $\begin{array}{l}14,15,17 \\
83,88,90\end{array}$ & $\begin{array}{l}15 \\
87\end{array}$ \\
\hline
\end{tabular}

* Experimental details as given in Table II. in vitro test can be employed as a dependable reflection of the exact viability of the erythrocyte.

Cells damaged during storage in ACD are removed from circulation within the first 24 to 48 hours after transfusion. The slope of the survival curve after 24 hours of the treated transfused cells in these studies was similar to that observed with ACD blood followed four weeks. It is believed, therefore, that any damage incurred by storage to the cells with added adenosine was completely reflected by the measurements made during the first seven days after transfusion.

It is well known that the erythrocyte is dependent upon carbohydrate metabolism to meet certain energy requirements if viability is to be maintained. At $4^{\circ}$, viability is lost rapidly if glucose is removed, or if inhibitors such as fluoride or oxalate are added. Thus in these studies in which attention has been focused on the red cell phosphate partition as a metabolic indicator, the marked improvement in this system observed after the incubation of stored blood with adenosine was considered indicative of improvement in the preservation of the erythrocyte.

The data presented in this report emphasize the inter-relationship between the energy potential of the red cell and viability. Adenosine not only restores organic phosphorylated compounds, but the osmotic resistance and the potassium content as well. Post-transfusion survival studies clearly indicate that these alterations have been reflected in improved preservation of blood.

\section{SUMMARY}

The reversal of the storage lesion with adenosine has been demonstrated in rabbit and human blood stored at $4^{\circ} \mathrm{C}$. in ACD and has been characterized by in vitro changes and by the effect on post-transfusion survival.

The incubation of three-week stored blood with adenosine for one hour at $37^{\circ} \mathrm{C}$. resulted in the regeneration of organic phosphates, improvement in osmotic fragility, and increase in intracellular potassium. These changes were sustained for a subsequent three-week interval at refrigeration temperature.

There was an associated improvement in posttransfusion viability of adenosine-treated cells over the second three-week period as compared with control ACD blood. 
The evidence would seem to indicate that a diminished energy potential of the cell is a primary factor in the deterioration of the erythrocyte under these conditions of storage.

\section{ACKNOWLEDGMENT}

The authors wish to thank Miss Marion Hennessey, Mrs. Joan Thomasson, Mrs. Eloise Hardin, and Mrs. Olga Matson for expert technical assistance.

\section{REFERENCES}

1. Gabrio, B. W., Stevens, A. R., Jr., and Finch, C. A., Erythrocyte preservation. III. The reversibility of the storage lesion. J. Clin. Invest., 1954, 33, 252.

2. Gabrio, B. W., Hennessey, M., Thomasson, J., and Finch, C. A., Erythrocyte preservation. IV. The in vitro reversibility of the storage lesion. J. Biol. Chem., 1955, 215, 357.

3. Shen, S. C., and Ham, T. H., Studies on the destruction of red blood cells. III. Mechanism and complications of hemoglobinuria in patients with thermal burns: Spherocytosis and increased osmotic fragility of red blood cells. New England J. Med., 1943, 229, 701.

4. Donohue, D. M., Motulsky, A. G., Giblett, E. R., Pirzio-Biroli, G., Viranuvatti, V., and Finch, C. A., Brit. J. Hematology, In press. 